\title{
Penerapan Model Think Talk Write untuk Meningkatkan Keterampilan Menulis Parafrasa Puisi pada Siswa SMK Negeri 3 Singkawang Tahun Ajaran 2016/2017
}

\author{
Erina $^{1)}$, Susan Neni Triani ${ }^{2)}$ Wahyuni Oktavia ${ }^{3)}$ \\ 1. Program Studi Pendidikan Bahasa dan Sastra Indonesia, STKIP Singkawang \\ E-mail: erinatariasga@yahoo.com \\ 2. Program Studi Pendidikan Bahasa dan Sastra Indonesia, STKIP Singkawang \\ E-mail: trianisusanneni@yahoo.com \\ 3. Program Studi Pendidikan Bahasa dan Sastra Indonesia, STKIP Singkawang, \\ E-mail: oktaviawahyuni9@gmail.com
}

\begin{abstract}
Abstrak. Penelitian berlatar belakang dikarenakan hasil belaar siswa khususnya pada materi menulis parafrasa puisi masih sangat rendah. Penelitian ini bertujuan untuk, 1. mengetahui nilai rata-rata hasil belajar sebelum dan sesudah penerapan model think talk write dalam menulis parafrasa puisi pada siswa kelas X SMK Negeri 3 Singkawang tahun pelajaran 2016/2017, 2. mengetahui keterlaksaan model think talk write dalam menulis parafrasa puisi pada siswa kelas X SMK Negeri 3 Singkawang pada siswa kelas X SMK Negeri 3 Singkawang tahun pelajaran 2016/2017, 3. mengetahui respon siswa terhadap penerapan model think talk write dalam menulis parafrasa puisi pada siswa kelas X SMK Negeri 3 Singkawang tahun pelajaran $2016 / 2017$. Penelitian ini menggunakan metode penelitian eksperimen dengan jenis penelitian quasi experimental design dan rancangan penelitian yang digunakan dalam penelitian ini adalah one group pretest-posttest control design dengan satu macam perlakuan. Adapun yang menjadi populasi dalam penelitian ini adalah seluruh siswa kelas X SMK Negeri 3 Singkawang dengan jumlah keseluruhan siswa sebanyak 148 orang. Penentuan sampel dengan teknik sampling purposive dan kelas yang terpilih menjadi kelas eksperimen adalah kelas X UPW 1. Hasil analisis data pretest dan posttest diketahui bahwa hasil belajar siswa menulis parafrasa puisi dengan menarapkan model pembelajaran think talk write mengalami peningkatan yang cukup signifikan. hal ini terlihat dari rata-rata hasil posttest sebesar 85,288 dan pretest sebesar 62, 857. Hasil keterlaksanaan penerapan model pembelajaran think talk write yang menunjukkan bahwa hasil keterlaksanaan mencapai 80,51\%. hasil dari sebaran angket yang dilakukan peneliti diperoleh hasil untuk kategori setuju (S) mencapai 47,50\%, sangat setuju (SS) mencapai 47,30\%, tidak setuju (TS) 5\%, dan sangat tidak setuju 0,19\%. Dari hasil yang diperoleh maka hasil penghitungan diperoleh dari uji hipotesis menunjukan $\mathrm{T}_{\text {hitung }} 9,958$ setelah dikonsultasikan dengan $\mathrm{T}_{\text {tabel }}$ pada taraf signifikansi 0,05 dan df sebesar 25 ternyata $\mathrm{T}_{\text {hitung }}$ lebih besar dari $\mathrm{T}_{\text {tabel }}(1,708)$ sehingga Ha yang menyatakan adanya peningkatan setelah diterapkannya model pembelajaran think talk write terhadap hasil belajar menulis parafrasa puisi pada mata pelajaran bahasa Indonesia di kelas X SMK Negeri 3 Singkawang diterima.
\end{abstract}

Kata Kunci : model think talk write; menulis; parafrasa puisi.

\section{PENDAHULUAN}

Menulis merupakan suatu keterampilan berbahasa yang dipergunakan untuk berkomunikasi secara tidak langsung. Dalam kegiatan menulis ini, peneliti harus terampil memanfaatkan struktur bahasa dan kosa kata (Tarigan, 2008:4). Terampil menulis yang dimaksud yaitu seorang pengarang atau peneliti mengelola struktur bahasa dan kosa kata. Sehingga pembaca menjadi tertarik dan penasaran dengan apa yang di bicarakan dalam tulisan tersebut. Terampil dalam menulis tidak hanya datang sendiri atau pun bakat yang alami. Tetapi agar bisa terampil dalam menulis haruslah melalui proses belajar bagaimana cara menulis yang baik. Tujuan umum penelitian ini adalah untuk mengetahui penerapan model think talk write untuk meningkatkan keterampilan menulis parafrasa puisi pada siswa kelas X SMK Negeri 3 Singkawang tahun pelajaran 2016/2017. Adapun tujuan khususnya adalah untuk mengatahui tentang. Nilai rata-rata hasil belajar sebelum dan sesudah penerapan model think talk write dalam menulis parafrasa puisi pada siswa kelas X SMK Negeri 3 Singkawang tahun pelajaran 2016/2017. Keterlaksaan model think talk write dalam menulis parafrasa puisi pada 
siswa kelas X SMK Negeri 3 Singkawang pada siswa kelas X SMK Negeri 3 Singkawang tahun pelajaran 2016/2017. Respon siswa terhadap penerapan model think talk write dalam menulis parafrasa puisi pada siswa kelas X SMK Negeri 3 Singkawang tahun pelajaran 2016/2017.

Hipotesis dalam penelitian ini dapat dirumuskan adalah hipotesis Alternatif (Ha) yang menyatakan adanya peningkatan setelah diterapkanya model pembelajaran think talk write untuk meningkatkan keterampilan menulis parafrasa puisi pada siswa kelas X SMK Negeri 3 Singkawang tahin pelajaran 2016/2017.

Menulis di pergunakan oleh orang terpelajar untuk mencatat atau merekam, meyakinkan, melaporkan atau memberitahukan dan mempengaruhi dengan maksud serta tujuan seperti itu hanya dapat di capai dengan baik oleh orang-orang yang dapat menyusun pikirannya dan mengutarakannya dengan jelas, kejelasan ini tergantung pada pikiran, organisasi, pemakai kata-kata dan struktur kalimat menurut Morsey (Tarigan,2008:4). Menurut Tarigan (2008:22) kemampuan seseorang sering dapat diketahui dan dapat di pahami oleh para pembaca dari tulisan-tulisannya. Menulis ialah menurukan atau melukiskan lambang-lambang grafik yang menggambarkan suatu bahasa yang di pahami seseorang. Sehingga orang-orang lain dapat membaca lambang-lambang grafik tersebut kalau mereka mengalami bahasa dan gambaran grafik itu. Gambar atau lukisanmungkin dapat menyampaikan makna-makna tetapi tidak menggambarkan kesatuan-kesatuan ekspresi bahasa oleh karena itu keterampilan menulis sangat dibutuhkan dalam kehidupan moderen.

Model pembelajaran merupakan sebuah kesatuan atau sistematika berlangsungnya sebuah kegiatan pembelajaran (Safrihady dan Oktavia: 2015). Model pembelajaran dapat dikatakan sebagai bentuk pembelajaran yang ingin dilaksanakan guru di kelas. Suprijono (2009:41) menjelaskan "Model pembelajaran merupakan landasan praktik pembelajaran hasil penurunan teori psikologi pendidikan dan teori belajar yang dirancang berdasarkan analisis terhadap implementasi kurikulum dan implikasinya pada tingkat operasional di kelas". Rusman (2014:133) mengungkapkan sebelum menentukan model pembelajaran yang akan digunakan dalam kegiatan pembelajaran, ada hal yang mesti dipertimbangkan dalam memilihnya sebagai berikut, pertimbangkan terhadap tujuan yang akan dicapai, pertimbangan yang berhubungan dengan bahan atau materi pembelajaran, pertimbangan dari sudut peserta didik atau siswa, pertimbangkan lainnya yang bersifat nonteknis.

Model pembelajaran TTW (think-talk-write) merupakan suatu model pembelajaran komunikatif suatu bacaan secara menyeluruh kemudian mengomposisikannya menjadi bagian-bagian penting. Model TTW memperkenalkan siswa untuk memengaruhi dan memanipulasi ide-ide sebelum menuangkannya dalam bentuk tulisan dan membantu siswa dalam mengumpulkan dan mengembangkan ide-ide melalui percakapan terstruktur. Huda (2014:218-219) Model TTW memiliki sintak yang sesuai dengan di dalamnya, yakni think (berpikir), talk (berbicara), dan write (menulis). Model pembelajaran think talk write diperkenalkan oleh Huinker dan Laughlin (dalam Istarani dan Ridwan, 2014: 55). Pada dasarnya di bangun melalui berpikir, berbicara dan menulis, model pembelajaran think talk write dimulai dari keterlibatan siswa dalam berpikir atau berdialog dengan dirinya sendiri setelah proses membaca, selanjutnya berbicara dan berbagi ide (sharing) dengan temanya sebelum menulis. suasana seperti ini lebih efektif jika di lakukan dengan kelompok hetergen dengan 35 siswa. Dalam kelompok ini siswa di minta membaca, membuat catatan kecil, menjelaskan, mendengar dan membagi ide bersama teman kemudian mengungkapkan melalui tulisan.

Parafrasa adalah pengungkapan kembali suatu tuturan bahasa kedalam bentuk bahasa lain tanpa mengubah pengertian. Menurut Kridalaksana (1993:154) parafrasa adalah pengungkapan kembali konsep dengan cara lain dalam bahasa yang sama tanpa mengubah maknanya dengan memberi kemungkinan penekanan agak berlainan. Parafrasa adalah penguraian kembali isi sebuah kalimat atau penggalan teks dengan cara menggunakan kata-kata lain yang bermaksud memperjelas isi teks.Pembelajaran menulis parafrasa puisi dengan menerapkan model think talk write merupakan suatu upaya yang peneliti lakukan bersama guru mata pelajaran bahasa Indoesia dengan harapan dapat memperbaiki permasalahan yang terjadi dalam menulis parafrasa puisi di kelas X SMK Negeri 3 Singkawang. Melalui model think talk write siswa di bimbing untuk memahami materi pembelajaran menulis parafrasa puisi serta membangun komunikasi yang baik dengan sesama siswa dalam berdiskusi dan membahas berbagai pendapat yang dikemukakan dalam menanggapi wacana yang di baca dan di dengar

\section{METODE.}

Metode penelitian merupakan suatu cara yang diambil untuk melaksanakan penelitian. Metode penelitian merupakan "Penelitian yang dilaksanakan secara terencana dan cermat dengan maksud mendapatkan fakta dan simpulan agar dapat memahami, menjelaskan, meramalkan, dan mengendalikan keadaan". Menurut Sugiyono (2010:13) "Metode kuantitatif adalah metode penelitian yang berlandaskan pada filsafat positivisme, digunakan untuk meneliti populasi atau sampel tertentu, pengumpulan data menggunakan instrumen penelitian, analisis data bersifat kuantitatif atau statistik dengan tujuan untuk menguji hipotesis yang telah ditetapkan. Metode penelitian yang digunakan dalam penelitian ini adalah metode eksperimen dengan bentuk penelitian Quasi-Experimental. Rancangan penelitian yang digunakan dalam penelitian ini adalah One Group Pretes-Postte Design dengan satu macam perlakuan. Dalam penelitian ini populasi yang akan diteliti adalah jumlah keseluruhan siswa kelas $X$ SMK Negeri 3 Singkawang dengan jumlah keseluruhan siswa sebanyak 148 orang. penelitian ini, peneliti menentukan jumlah sampel dengan menggunakan teknik nonprobability sampling. Adapun jenis nonprobability sampling adalah sampling purposive. Dalam penelitian ini terdiri dari variabel yang meliputi, variabel bebas (independen): Penerapan 
model pembelajaran think talk write dan variabel terikat (dependen) : hasil belajar siswa dalam menulis parafrasa puisi

Teknik dan alat pengumpul data yang digunakan dalam penelitian ini adalah menggunakan teknik komunikasi langsung, teknik observasi langsung, teknik pengukuran, dan teknik komunikasi tidak langsung berdasarkan teknik yang digunakan maka instrumen yang digunakan dalam penelitian ini adalah lembar observasi, angket dan tes. Setelah menentukan teknik dan instrumen yang digunakan maka validasi yang digunakan dalam penelitian ini menggunakan validasi isi dengan teknik expert judgement. Setelah instrumen dinyatakan valid, peneliti melakukan uji coba instrumen di SMK Mudita Singkawang hasil dari uji coba instrumen diukur dan diuji tingkat reliabilitasnya dengan menggunakan rumus koefisien reliabilitas alpha cronbach.

Untuk menganalisis data yang diperoleh dari pretest dan posttest dapat dilakukan dengan cara menghitung hasil ratarata hasil belajar sebelum dan sesudah penerapan model pembelajaran think talk write dengan menggunakan rumus mean. Sedangkan untuk mengetahui hasil dari keterlaksanaan dari penerapan model pembelajaran think talk write dapat diukur dengan menggunakan rumus respon. Pengukuran hasil angket siswa didapat dari hasil perhitungan dengan rumus respon. Sebagai langkah akhir dari analisis data akan diuji hipotesis dengan bantuan rumus uji $\mathrm{T}$.

\section{HASIL DAN PEMBAHASAN}

Berdasarkan hasil penelitian dan analisis data, maka dapat diketahui hasil belajar siswa menulis parafrasa puisi dengan menarapkan model pembelajaran think talk write mengalami peningkatan yang cukup signifikan. hal ini terlihat dari rata-rata hasil posttest sebesar 85,288 dan pretest sebesar 62,857 . Adapun faktor yang menyebabkan meningkatnya hasil belajar siswa adalah sebagai berikut.

1) Model pembelajaran think talk write mendorong peserta didik menjadi lebih aktif dalam proses pembelajaran.

2) Model pembelajaran think talk write membuat siswa menjadi kompak dalam pembelajaran kelompok.

3) Model pembelajaran think talk write melatih siswa dalam proses pengumpulan informasi yang berkaitan dengan materi pelajaran.

4) Model pembelajaran think talk write membuat siswa senang pada proses pembelajaran.

Model pembelajaran think talk write sangat baik digunakan dalam proses pembelajaran menulis parafrasa puisi, hal ini dikarenakan dengan diterapkannya model pembelajaran think talk write membuat siswa menjadi lebih aktif dan bersemangat dalam proses pembelajaran.

Hasil keterlaksanakan ditunjukan dari hasil keterlaksanaan penerapan model pembelajaran think talk write yang menunjukkan bahwa hasil keterlaksanaan mencapai 85,14\%. Perolehan hasil keterlaksanaan berdasarkan observasi yang dilakukan oleh guru bidang studi pada saat peneliti melakukan penelitian di dalam kelas. Dengan besarnya hasil keterlaksanaan ini maka penelitian yang dilakukan peneliti dengan menerapkan model pembelajaran think talk write menunjukan bahwa model pembelajaran ini mampu memberikan dampak baik dalam proses pembelajaran yang berlangsung selama penelitian.

Berdasarkan sebaran angket yang dilakukan peneliti diperoleh hasil untuk kategori setuju (S) mencapai 47,50\%, sangat setuju (SS) mencapai 47,31\%, tidak setuju (TS) 5\%, dan sangat tidak setuju $0,19 \%$ dari hasil tersebut maka dapat disimpulkan bahwa keseluruhan respon siswa positif terhadap pembelajaran menulis parafrasa puisi dengan menerapkan model pembelajaran think talk write.

\section{SIMPULAN DAN SARAN}

Simpulan yang berkaitan dengan hasil penelitian yang telah diperoleh adapun pejelasannya sebagai berikut, nilai ratarata hasil belajar sebelum dan sesudah penerapan model think talk write dalam menulis parafrasa puisi pada siswa kelas X SMK Negeri 3 Singkawang tahun pelajaran $2016 / 2017$ adalah 62,857 pada tahap pretest dan 85,288 pada tahap posttest hasil ini menunjukan adanya peningkatan hasil belajar siswa, keterlaksaan model think talk write dalam menulis parafrasa puisi pada siswa kelas X SMK Negeri 3 Singkawang pada siswa kelas X SMK Negeri 3 Singkawang tahun pelajaran 2016/2017 adalah dengan rata-rata 85,14\% terlaksana denga kategori sangat baik dan respon siswa terhadap penerapan model think talk write dalam menulis parafrasa puisi pada siswa kelas X SMK Negeri 3 Singkawang tahun pelajaran 2016/2017 adalah untuk kategori setuju (S) mencapai 47,50\%, sangat setuju (SS) mencapai $47,31 \%$, tidak setuju (TS) $5 \%$, dan sangat tidak setuju $0,19 \%$ dengan kriteria respon sangat baik.

Berdasarkan kesimpulan dan hasil penelitian yang telah dikemukakan di atas, saran untuk penelitian ini adalah sebagai berikut.

1. Guru bahasa Indonesia

Menggunakan model pembelajaran yang bervariasi dalam proses pembelajaran khususnya dalam pembelajaran menulis parafrasa puisi. Salah satu model pembelajaran yang dapat digunakan dalam pembelajaran yang berkaitan dengan sastra adalah model pembelajaran think talk write khususnya pembelajaran menulis parafrasa puisi.

2. Siswa

Diharapkan dengan hasil penelitian ini siswa menjadi lebih paham tentang materi yang dipalajarinya secara khusus dalam meningkatkan hasil belajar menulis parafrasa puisi .

3. Sekolah

Diharapkan pihak sekolah harus lebih meninjau kembali kelengkapan sarana dan prasarana pembelajaran sehingga akan mempermudah guru dalam merencanakan pembelajaran dengan menggunakan model pembelajaran.

\section{DAFTAR PUSTAKA}

Istarani \& Ridwan. (2014). 50 Tipe Pembelajaran Kooperatif. Medan: Media Persada. 
Harimurti Kridalaksana, (2008). Kamus Lingustik. Jakarta: gramedia Pustaka Utama.

Huda, Miftahul. (2014). Model-Model Pengajaran dan Pembelajaran. Yogyakarta: Pustaka Pelajar.

Purnama, Risma. (2014).Cooperatif Learning. Pontianak : STAIN Pontianak Pres.

Rusman. (2013). Model-model Pembelajaran. Jakarta: PT Raja Grafindo Persada.

Safrihady, S., \& Oktavia, W. (2015). INOVASI MODEL PARTISIPASI SOLUSI (PARTISOL) UNTUK MENINGKATKAN KETERAMPILAN BERBICARA SISWA. SEMNASPBI (Seminar Nasional Pendidikan Bahasa Indonesia) 2015.

Sugiyono. (2010). Metode Penelitian Kuantitatif, Kualitatif dan $R$ \& $D$. Bandung: Alfabeta.

Suprijono, Agus. (2009). Cooperatif Learning Teori dan Aplikasi Paikem. Yogyakarta. Pustaka Pelajar.

Tarigan, Henry Guntur. (2008). Menulis sebagai suatu Keterampilan Berbahasa. Bandung: Angkasa. 